\title{
The binding of an anti-PD-1 antibody to FcyRI has a profound impact on its biological functions
}

\author{
Tong Zhang ${ }^{1} \cdot$ Xiaomin Song ${ }^{1} \cdot$ Lanlan Xu $^{1}{ }^{1}$ Jie Ma ${ }^{1} \cdot$ Yanjuan Zhang ${ }^{1} \cdot$ Wenfeng Gong ${ }^{1} \cdot$ Yilu Zhang $^{1} \cdot$ Xiaosui Zhou $^{1}$.

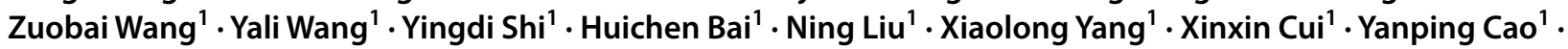 \\ Qi Liu ${ }^{1}$. Jing Song ${ }^{1} \cdot$ Yucheng $\mathrm{Li}^{1} \cdot$ Zhiyu Tang $^{1} \cdot$ Mingming Guo ${ }^{1} \cdot$ Lai Wang $^{1} \cdot$ Kang Li $^{1}$
}

Received: 7 July 2017 / Accepted: 4 April 2018 / Published online: 23 April 2018

(c) The Author(s) 2018

\begin{abstract}
Antibodies targeting PD-1 have been demonstrated durable anti-cancer activity in certain cancer types. However, the antiPD-1 antibodies are less or not efficacious in many situations, which might be attributed to co-expression of multiple inhibitory receptors or presence of immunosuppressive cells in the tumor microenvironment. Most of the anti-PD-1 antibodies used in clinical studies are of $\mathrm{IgG} 4$ isotype with the S228P mutation $\left(\mathrm{IgG}_{\mathrm{S} 228 \mathrm{P}}\right)$. The functional impact by the interaction of anti-PD-1 IgG4 ${ }_{\mathrm{S} 228 \mathrm{P}}$ antibody with $\mathrm{Fc}$ gamma receptors $(\mathrm{Fc} \gamma \mathrm{Rs})$ is poorly understood. To assess the effects, we generated a pair of anti-PD-1 antibodies: BGB-A317/IgG4 ${ }_{\text {S228P }}$ and BGB-A317/IgG4-variant (abbreviated as BGB-A317), with the same variable regions but two different IgG4 Fc-hinge sequences. There was no significant difference between these two antibodies in binding to PD-1. However, BGB-A317/IgG4 $4_{\mathrm{S} 228 \mathrm{P}}$ binds to human $\mathrm{Fc} \gamma \mathrm{RI}$ with high affinity and mediates crosslinking between PD-1 and Fc $\gamma$ RI. In contrast, BGB-A317 does neither. Further cell-based assays showed that such crosslinking could reverse the function of an anti-PD-1 antibody from blocking to activating. More importantly, the crosslinking induces $\mathrm{Fc} \gamma \mathrm{RI}^{+}$macrophages to phagocytose PD- ${ }^{+} \mathrm{T}$ cells. In a mouse model transplanted with allogeneic human cancer cells and PBMCs, BGB-A317 showed significant tumor growth inhibition, whereas BGB-A317/IgG4 ${ }_{\mathrm{S} 228 \mathrm{P}}$ had no such inhibition. Immunohistochemistry study revealed an inverse correlation between $\mathrm{Fc}_{\mathrm{RI}}{ }^{+}$murine macrophage infiltration and the density

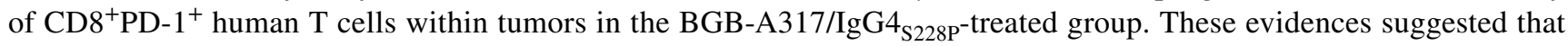
Fc $\gamma \mathrm{RI}^{+}$binding and crosslinking had negative impact on the anti-PD-1 antibody-mediated anti-cancer activity.
\end{abstract}

Keywords PD- $1 \cdot$ Antibody $\cdot$ Fc $\gamma \mathrm{RI} \cdot$ Macrophages $\cdot$ Cancer therapy

$\begin{array}{ll}\text { Abbreviations } & \\ \text { ADCP } & \text { Antibody-dependent cell phagocytosis } \\ \text { CTL } & \text { Cytotoxic T cell } \\ \text { Fc } \gamma \text { R } & \text { Fc gamma receptor } \\ \text { IL-2 } & \text { Interleukin 2 } \\ \text { IL-6 } & \text { Interleukin 6 } \\ \text { IL-8 } & \text { Interleukin 8 }\end{array}$

Tong Zhang and Xiaomin Song contributed equally to this study.

Electronic supplementary material The online version of this article (https://doi.org/10.1007/s00262-018-2160-x) contains supplementary material, which is available to authorized users.

Kang Li

kang.li@beigene.com

1 BeiGene (Beijing) Co., Ltd., No. 30 Science Park Road, Zhong-Guan-Cun Life Science Park, Changping District, Beijing 102206, People's Republic of China

$\begin{array}{ll}\text { IL-10 } & \text { Interleukin } 10 \\ \text { LAMP1 } & \begin{array}{l}\text { Lysosomal-associated membrane pro- } \\ \text { tein } 1\end{array} \\ \text { M2 macrophages } & \text { Type 2 macrophages } \\ \text { MDSC } & \text { Myeloid-derived suppressor cell } \\ \text { MFI } & \text { Mean fluorescence intensity } \\ \text { PBMC } & \text { Peripheral blood mononuclear cell } \\ \text { PD-1 } & \text { Programmed cell death-1 } \\ \text { PD-L1 } & \text { Programmed cell death-ligand 1 } \\ T_{\text {eff }} & \text { T effector cell } \\ \text { TNF- } \alpha & \text { Tumor necrosis factor- } \alpha\end{array}$

\section{Introduction}

Immune surveillance plays a critical role in cancer prevention. However, in situations where tumors develop resistance mechanisms to suppress the host immune system, tumors 
eventually grow out of control $[1,2]$. One of such resistance mechanism is the up-regulation of the immune check-point ligand, PD-L1, in tumor cells or in tumor-associated immune cells. PD-L1 interacts with PD-1 (programmed cell death-1) on $\mathrm{T}$ cells, inhibiting T-cell proliferation and effector functions such as cytokine secretion and tumor cell-killing [3, 4]. Several PD-1 antagonist antibodies have been tested in clinical trials, and show significant efficacy in the treatment of advanced cancer types [5-9]. Two anti-PD-1 antibodies, nivolumab, and pembrolizumab recently gained regulatory approval [3].

Antibody drugs exert primary pharmacodynamic effects through specific binding to a target protein and modulating its functional activity via the variable regions. Furthermore, the constant region of an antibody also plays important roles by exerting secondary pharmacodynamic effects through the binding to Fc $\gamma$ Rs or activation of complement cascade. Each IgG subclass has a unique set of features for binding to effector receptors that elicit profound functional effects on the target cells $[10,11]$.

Most of the anti-PD-1 monoclonal antibodies (mAb), including nivolumab and pembrolizumab, have $\mathrm{IgG}_{\mathrm{S} 228 \mathrm{P}}$ heavy chain, which retains effector-binding functions similar to that of wild-type human IgG4 [11], while it possesses more stable dimeric structure without fab-arm exchange observed in wild-type IgG4 $[12,13]$. It was well documented that human IgG4 has significant binding to high affinity Fc $\gamma \mathrm{RI}$ through the $\mathrm{Fc}$-hinge regions [11]. IgG4 $4_{\mathrm{S} 228 \mathrm{P}}$ antibodies likely retain the binding to Fc $\gamma$ RI. In a syngeneic mouse model, an anti-PD-1 mAb with "effector-less" Fc region demonstrated superior anti-tumor efficacy as compared with the one with effector functions [14]. However, functional consequences of $\mathrm{Fc} \gamma \mathrm{RI}$ engagement by anti-PD-1 $\mathrm{mAb}$ through $\mathrm{IgG} 4_{\mathrm{S} 228 \mathrm{P}}$ have not been well studied.

Fc $\gamma \mathrm{RI}$ is highly expressed in type 2 macrophages (M2) under inflammatory conditions in certain tumor types [15]. It is also expressed in myeloid-derived suppressor cells (MDSCs) and type I macrophages (M1). The functions induced by Fc $\gamma \mathrm{RI}$ engagement span a wide scope of cellular activities including antibody-dependent cell phagocytosis (ADCP), cell proliferation, and production of cytokines depending on the cell type in which FcyRI is activated [16].

In this report, we studied the functional consequences of an anti-PD-1 mAb with an IgG4 ${ }_{S 228 P}$ heavy chain, for which we generated a pair of anti-PD-1 antibodies with the same variable regions, but with different forms of the IgG4 heavy chain: BGB-A317/IgG4 ${ }_{\text {S228P }}$ (with a single S228P mutation) and BGB-A317 (lack of Fc $\gamma$ R-binding capacity). Comparative characterization of these two mAbs demonstrated that BGB-A317/IgG4 $4_{S 228 \mathrm{P}}$ binds to human Fc $\gamma$ RI with high affinity and mediates crosslinking between PD- $1^{+} \mathrm{T}$ cells and $\mathrm{Fc}_{\mathrm{RRI}}{ }^{+}$cells. In addition, the two BGB-A317 mAbs showed profound differences in their capacity to modulate T-cell and macrophage functions in vitro or inhibit tumor growth using xenograft model in vivo.

\section{Materials and methods}

\section{Binding affinity assay by SPR}

For the characterization of the binding affinity of BGBA317 or BGB-A317/IgG4 ${ }_{\text {S228P }}$ to human PD-1, the extracellular domain of the human PD-1 protein, with a His tag (PD-1/His), was coupled to an activated CM5 biosensor chip (Biacore ${ }^{\circledR}$, GE Healthcare Life Sci). BGB-A317 or BGB-A317/IgG4 $4_{S 228 P}$ samples were injected and binding responses to human PD-1/His were calculated by subtracting the response unit (RU) from the values measured for a blank flow cell. Association rates $\left(K_{\text {on }}\right)$ and dissociation rates $\left(K_{\text {off }}\right)$ were calculated using the BIA Evaluation Software (GE Life Sciences). The equilibrium dissociation constant $\left(K_{\mathrm{D}}\right)$ was calculated as the ratio of $K_{\text {off }} / K_{\text {on }}$, and binding affinity was calculated as $K_{\text {on }} / K_{\text {off }}$.

For the analysis of the binding of BGB-A317 and BGBA317/IgG4 $4_{\text {S228P }}$ to human Fc $\gamma$ RI, human PD-1/His was immobilized on a CM5 chip. Fc $\gamma$ RI was injected over a human PD-1/His-captured antibody surface. The sandwich binding of PD-1, BGB-A317/IgG4 ${ }_{\mathrm{S} 228 \mathrm{P}}$, and $\mathrm{Fc} \gamma \mathrm{RI}$ was performed by flowing Fc $\gamma$ RI protein on top of the PD-1, BGB-A317/IgG4 ${ }_{\mathrm{S} 228 \mathrm{P}}$ complex bound on the sensor chip. The same procedure was applied to BGB-A317.

\section{Generation of stable cell lines}

A Chimeric PD-1 receptor, P3Z, was constructed by fusing the extracellular and transmembrane domains of human PD-1 to the cytoplasmic domain of human CD3 $\zeta$ chain, which was stably transduced into HuT78 cells (ATCC) to generate HuT78/P3Z cells. The HEK293/PD-L1 and HEK293/Fc $\gamma$ RI cell lines were generated by stable transfection. HuT78/P3Z cells were cultured in complete RPMI1640 (Hyclone) supplemented with $10 \%$ heat-inactivated FBS (Corning), and incubated at $37{ }^{\circ} \mathrm{C}$ with $5 \% \mathrm{CO}_{2}$. HEK293based cell lines were cultured in DMEM (Invitrogen) supplemented with 10\% FBS (Corning).

\section{P3Z assays}

HuT78/P3Z cells were pre-incubated with BGB-A317 (0.0014-3 $\mu \mathrm{g} / \mathrm{mL})$ for $15 \mathrm{~min}$ prior to co-culturing with HEK293/PD-L1 cells in 96-well plates (Costar) containing complete RPMI1640 media. The cells were incubated for $17 \mathrm{~h}$ at $37{ }^{\circ} \mathrm{C}$. IL-2 secretion in the supernatants of coculture was assayed by ELISA using a kit from eBioscience, according to manufacturer's instructions. 


\section{Human PBMC separation}

Human peripheral blood mononuclear cells (PBMCs) were isolated from healthy donors by density gradient centrifugation using Histopaque-1077 (Sigma) according to the manufacturer's instructions. All procedures were approved by the Internal Review Board at BeiGene. Consent agreement forms were signed before blood donation.

\section{ELISA}

In the ELISA-based assay, bait proteins $(1 \mu \mathrm{g} / \mathrm{mL}, 100 \mathrm{ng} /$ well) were coated onto MaxiSorp plates (Thermo Fisher). For BGB-A317 antibody binding to PD-1, the bait protein is PD-1/his. For assessing antibody and Fc $\gamma \mathrm{R}$ binding, the extracellular domain of Fc $\gamma$ R, e.g., Fc $\gamma \mathrm{RI} / \mathrm{his}$, was coated in the wells. A preformed immune-complex mixture was added to wells and incubated at room temperature for 1-2 h. The preforming immune-complex reaction contained $60 \mathrm{ng} / \mathrm{mL}$ streptavidin-HRP, $60 \mathrm{ng} / \mathrm{mL}$ of biotinylated $\mathrm{F}\left(\mathrm{ab}^{\prime}\right) 2$ goat anti-human $\operatorname{IgG}\left(\mathrm{F}\left(\mathrm{ab}^{\prime}\right) 2\right)$ (Jackson ImmunoRes, USA), and $1 \mu \mathrm{g} / \mathrm{mL}$ of BGB-A317 or BGB$\mathrm{A} 317 / \mathrm{IgG} 4_{\mathrm{S} 228 \mathrm{P}}$ or human $\operatorname{IgG}$ (huIgG) in the blocking buffer. ELISA-binding signals were detected by Immobilon chemiluminescence substrate A/B (Millipore).

\section{Generation of M2 macrophages}

Generation of M2 macrophages was performed according to the protocol described by Leidi et al. [15]. Briefly, human PBMCs were co-cultured in 6-well plates or 100$\mathrm{mm}$ culture dish (Corning) in complete RPMI1640 media supplemented with $30 \mathrm{ng} / \mathrm{ml}$ human M-CSF (R\&D systems) for 4 days. Adherent cells were retained by gently washing off non- and loose-adherent cells, with half of media replaced, and culture for 2-3 more days. For M2 polarization, $10 \mathrm{ng} / \mathrm{ml} \mathrm{IL-10} \mathrm{(Peprotech)} \mathrm{was} \mathrm{added} \mathrm{during}$ the last $48 \mathrm{~h}$ of culture.

\section{ADCP}

HuT78/PD-1 cells were labeled with carboxyfluorescein succinimidyl ester (CFSE) (Life technologies) according to the manufacturer's instructions. M2 macrophages were detached by Accutase ${ }^{\mathrm{TM}}$ and plated in V-bottom 96-well plates with CFSE-labeled HuT78/PD-1 at a ratio of 2:1 (HuT78/PD-1 cell to macrophage) in the presence of PD-1 mAbs for $5 \mathrm{~h}$ at $37{ }^{\circ} \mathrm{C}$. After co-culturing, cells were stained with antiCD11b-APC and subjected to flow cytometry. The percentage of macrophages that underwent ADCP of HuT78/PD-1 was determined by FACS of double positive cells $\left(\mathrm{CFSE}^{+}\right.$ and $\mathrm{CD} 11 \mathrm{~b}^{+}$) following gating on $\mathrm{CD} 11 \mathrm{~b}^{+} \mathrm{M} 2$ macrophages.

\section{FACS analysis}

FACS analysis was performed using Guava ${ }^{\circledR}$ easyCyte 6HT or 8HT (Millipore Merck). For the cell-based-binding assay, Fc $\gamma$ RI-transfected HEK293 cells (HEK293/Fc $\gamma$ RI) were stained with BGB-A317 or BGB-A317/IgG4 ${ }_{\mathrm{S} 228 \mathrm{P}}$ or huIgG, followed by detection with AlexaFluor 488-conjugated goat $\mathrm{F}\left(\mathrm{ab}^{\prime}\right) 2$ anti-human IgG ( $\left.\mathrm{F}\left(\mathrm{ab}^{\prime}\right) 2\right)$ fragment (Jackson ImmunoRes). The cell surface binding signals were quantified as mean fluorescence intensities (MFIs).

For the analysis of tumor infiltrated immune cells from the mouse in vivo cancer models, tumor tissue was cut into small pieces and digested with collagenase type I $(1 \mathrm{mg} / \mathrm{ml}$, Sigma) and $100 \mu \mathrm{g} / \mathrm{ml}$ DNase I (Sigma) in RPMI1640 plus $5 \% \mathrm{FBS}$ for $30 \mathrm{~min}$ at $37{ }^{\circ} \mathrm{C}$. Single cell suspension was obtained after passing the digested tissues through a $70 \mu \mathrm{m}$ cell strainer. The cells were then washed and blocked by human IgG, followed by staining with human CD3 (HIT3a, 4A biotech), CD8 (OKT8, Sungene biotech), PD-1 (MIH4, eBioscience), CD64 (10.1, eBioscience), or mouse CD64 (X54-5/7.1, Biolegend) antibodies at $4{ }^{\circ} \mathrm{C}$. The stained samples were subjected to flow cytometry and analysis using guavaSoft3.1.1 (Millipore, Merck).

\section{In vivo efficacy study}

NOD/SCID mice (purchased from Vital River) were pretreated with cyclophosphamide $(150 \mathrm{mg} / \mathrm{kg}, \mathrm{J} \& \mathrm{~K})$ intraperitoneally (i.p.) once a day for 2 days. One day after the second dose, animals were injected subcutaneously (s.c.) with $2.5 \times 10^{6}$ A431 cells (ATCC) and $5 \times 10^{6}$ PBMCs (a total of $200 \mu \mathrm{l}$ cell mixture in $50 \%$ matrigel) in the right front flank. Starting from day 0 after cell inoculation, animals were randomly grouped and then treated as indicated. Primary tumor volume was measured twice every week, using a caliper. All experiments were conducted based on the protocols approved by the Animal Care and Use Committee of BeiGene according to the guidelines of the Chinese Association for Laboratory Animal Sciences.

\section{Pharmacokinetics analysis of BGB-A317 and BGB-A317/lgG4 S228P $_{\text {P }}$}

Mouse blood samples were collected from retro-orbital sinus at indicated time points. The concentration of BGB-A317 or BGB-A317/IgG4 ${ }_{\text {S228P }}$ in serum was determined by ELISA. Briefly, serum samples were added to PD-1/His protein ( $2 \mu \mathrm{g} / \mathrm{ml}$ )-coated ELISA plates (Nunc), followed by the capture with anti-huIgG-HRP (Sigma) and color development. OD values at $450 \mathrm{~nm}$ were detected by a Microplate Reader 
(SpectraMax ${ }^{\circledR}$ Paradigm ${ }^{\circledR}$ ). The results were analyzed with SoftMax Pro software (Molecular Devices).

\section{IHC and immunofluoresence staining}

Tumor tissues were harvested and fixed in formalin, dehydrated, embedded in paraffin, sectioned at $3 \mu \mathrm{m}$, and placed on polylysine-coated slides. The sections were deparaffinized in xylene and rehydrated in graded ethanol. Antigen retrieval was performed in citrate buffer ( $\mathrm{pH}$ 6.0) by boiling for $30 \mathrm{~min}$ in a microwave and cooling down to room temperature. Then, the sections were blocked by $3 \%$ bovine serum albumin in PBS for $1 \mathrm{~h}$ and $0.3 \% \mathrm{H}_{2} \mathrm{O}_{2}$ solution in PBS for $10 \mathrm{~min}$, and afterwards, stained by the antibodies against human CD8 (SP16, ZSGB-Bio), PD-1 (NAT105, Abcam), CD64 (3D3, Abcam), and mouse CD64 (Clone 027, Sino Biological) at $4{ }^{\circ} \mathrm{C}$ overnight. The antibodies were detected by HRP conjugated second antibodies and DAB. The immunofluorescence staining was performed using Opal ${ }^{\mathrm{TM}} 4$ or 7 -color immunofluorescence staining kits (PerkinElmer). The images were acquired on the Vectra System and were analyzed using inForm software (both from PerkinElmer).

\section{Statistical analysis}

Student's $t$ test was used to analyze differences between groups. $P<0.05$ was considered statistically significant. Statistical analysis was done by GraphPad Prism software (GraphPad, La Jolla, CA).

\section{Results}

\section{Generation of anti-PD-1 antibodies with different binding properties to FcyRs}

The humanized anti-PD-1 mAb, hu317-4b6 (published in the patent US8735553 B1), binds to human PD-1 with high affinity and blocks PD-1 ligand (either PD-L1 or PD-L2)mediated signaling (data not shown). To investigate the functionality of anti-PD-1 IgG4 antibodies with or without Fc-mediated effector functions, the variable region of hu317 was linked to two variant forms of human IgG4 constant regions, respectively, resulting in two different antibodies. One, named BGB-A317 (being tested in clinical trial, ClinicalTrials.gov number: NCT02407990), is incapable of binding to FcyRs due to several mutations in its Fc-hinge region. The other antibody, referred to as BGB-A317/IgG4 ${ }_{\mathrm{S} 228 \mathrm{P}}$, is identical to the wild-type IgG4 except S228P mutation. The majority of anti-PD-1 antibodies (including nivolumab and pembrolizumab) are of the $\mathrm{IgG}_{\mathrm{S} 228 \mathrm{P}}$ format. The differences of three IgG4 formats, including wild type, S228P and that of BGB-A317, are shown by sequence alignment of the Fchinge regions (Suppl. Figure 1).

Binding assays using SPR technology demonstrated that both BGB-A317 and BGB-A317/IgG4 ${ }_{\text {S228P }}$ bind to PD-1 equally well (Fig. 1a, b). FACS analysis of antibody binding to surface PD-1 showed similar results (Fig. 1c). However, the two antibodies have very different binding affinity to certain Fc $\gamma$ Rs, most notably, Fc $\gamma$ RI (high affinity Fc $\gamma R$ ). BGB$\mathrm{A} 317 / \mathrm{IgG}_{\mathrm{S} 228 \mathrm{P}}$ binds to Fc $\gamma \mathrm{RI}$ with high affinity $\left(K_{A}\right)$ and low dissociation constant $\left(K_{D}\right)$ (Fig. 1d and Suppl. Table 1), and it also has significant binding to FcyRIIA and Fc $\gamma$ RIIB (data not shown). In contrast, BGB-A317 has no binding to Fc $\gamma$ RI (Fig. 1d) as well as to other Fc $\gamma$ Rs. The Fc $\gamma$ R-binding profiles of BGB-A317/IgG4 $4_{\mathrm{S} 228 \mathrm{P}}$ are very similar to other IgG4 antibodies such as nivolumab and pembrolizumab (data not shown), as well as those reported for regular human IgG4 $[10,17]$. BGB-A317/IgG4 ${ }_{\text {S228P }}$ exhibits low binding to FcyRIIIA (Fig. 1e), in consistent with other $\operatorname{IgG}_{\mathrm{S} 228 \mathrm{P}}$ antibodies.

\section{BGB-A317/lgG4 ${ }_{\text {S228P }}$ but not BGB-A317 mediates the crosslinking between PD-1 and FcyRI}

The functions of an antibody are not only determined by its binding to the target protein but also impacted by Fcmediated effector functions. Since BGB-A317/IgG4 ${ }_{\mathrm{S} 228 \mathrm{P}}$ has significant binding to Fc $\gamma \mathrm{RI}$, we next investigated whether effective crosslinking between PD-1 and Fc $\gamma$ RI could be established by BGB-A317/IgG4 ${ }_{\text {S228P }}$ using SPR. The sensorgram readout clearly demonstrated that only BGB-A317/ $\mathrm{IgG}_{\text {S228P }}$ forms stable crosslinking between PD-1 and Fc $\gamma R I$ although both BGB-A317 and BGB-A317/IgG4 $4_{\text {S228P }}$ could bind to chip-bound PD-1 (Fig. 2a), which is explained by Fig. $2 b$.

The functional consequences of the crosslinking were tested by reverse signaling assay in cell co-culture system with or without the addition of Fc $\gamma R$-expressing myeloid cells (THP-1). Thus, PD-1 signaling upon crosslinking is manifested by T-cell activation. In the reverse signaling assay using two-cell co-culture system including the signal sensor cell, HuT78/P3Z, that expresses the chimeric PD-1 receptor (see "Materials and methods") and the signal sending cell, HEK293/PD-L1, The engagement of chimeric receptor P3Z with PD-L1 leads to activating, instead of inhibiting the sensor cell to secrete IL-2. In this system, both BGB-A317 and BGB-A317/IgG4 ${ }_{\text {S228P }}$ blocked PD1-mediated signaling equally well (Fig. 2c). However, the addition of a third cell line, THP-1 $\left(\mathrm{Fc} \gamma \mathrm{RI}^{+}\right)$, to the above two-cell co-culture system resulted in dramatic changes in BGB-A317/IgG4 ${ }_{S 228 P}$ function: inhibition of IL-2 secretion was reversed as the PD-1 antibody concentration increased (Fig. 2c), indicating that the crosslinking functions to activate PD-1-mediated signaling, rather than to block the T-cell 
Fig. 1 Comparison of BGBA317 and BGB-A317/IgG4 ${ }_{\mathrm{S} 228 \mathrm{P}}$ binding profiles to human PD-1, Fc $\gamma R I$, and Fc $\gamma$ RIIIA. a, b Realtime SPR sensorgrams of BGBA317 and BGB-A317/IgG4 ${ }_{\text {S228P }}$ binding to human PD-1 assayed using BIAcore. $Y$-axis, response unit (RU). $X$-axis, reaction time course, seconds. c Binding of BGB-A317 and BGB-A317/ $\mathrm{IgG}_{\mathrm{S} 228 \mathrm{P}}$ to HuT78/PD-1 cells assayed by FACS. Mean fluorescence intensity (MFI) was determined by flow cytometry. $\mathbf{d}$ Differential binding of BGB-A317 and BGB-A317/ $\mathrm{IgG}_{\mathrm{S} 228 \mathrm{P}}$ to $\mathrm{Fc} \gamma \mathrm{RI}$ assayed by FACS using HEK293/Fc $\gamma$ RI cells. e Both BGB-A317 and BGB-A317/IgG4 ${ }_{\text {S228P }}$ have low binding activity for Fc $\gamma$ RIIIA, determined by ELISA. The antiPD-1 antibodies were incubated with secondary antibodies to form immune complexes before adding to Fc $\gamma$ RIIIA-coated 96-well plates. Bound immune complexes were detected with a chemiluminescence substrate. $\mathrm{HuIgG}$ was used as a positive control

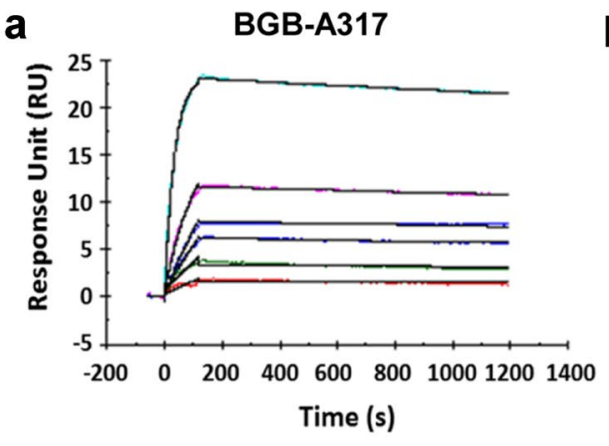

b
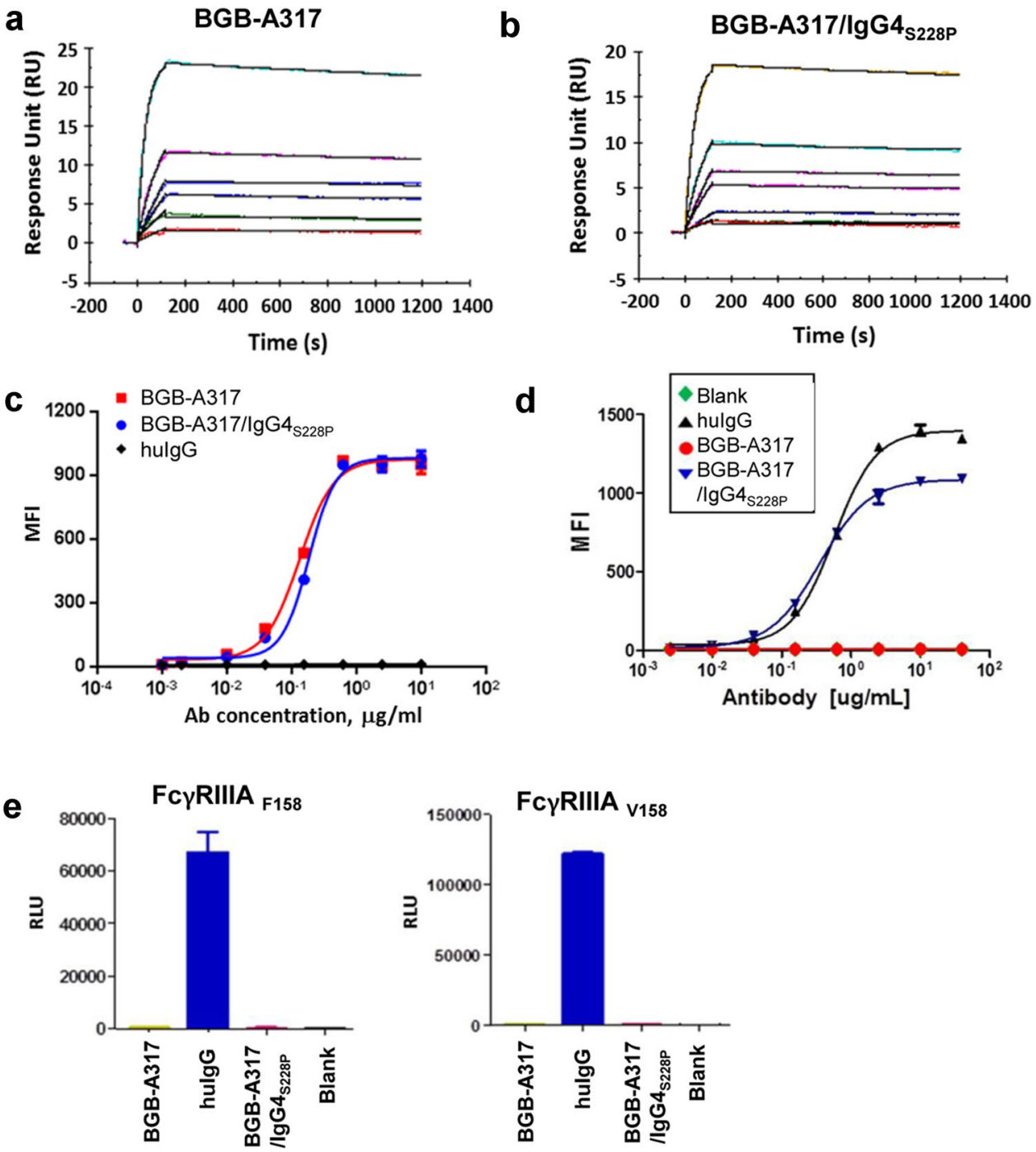

signaling in the sensor cells. In contrast, BGB-A317 function was not affected by the presence of $\mathrm{Fc} \gamma \mathrm{RI}^{+}$THP-1 in the co-culture assay (Fig. 2c).

To further determine the role of Fc $\gamma \mathrm{RI}$ in the crosslinking of PD-1 receptor, rabbit anti-CD64 (Fc $\gamma \mathrm{RI} \alpha$ subunit, or $\mathrm{Fc} \gamma \mathrm{RI} \alpha$ ) polyclonal antibodies were added to the system. As shown in Fig. 2d, BGB-A317/IgG4 ${ }_{\mathrm{S} 228 \mathrm{P}}$-mediated crosslinking was indeed reversed in the presence of anti-CD64 neutralizing antibody, suggesting that $\mathrm{Fc} \gamma \mathrm{RI}$ plays a major role in this process. These observations are consistent with previous findings that crosslinking can change an inhibitory antibody into an agonist antibody $[18,19]$.

\section{BGB-A317/lgG4 ${ }_{\text {S228P }}$ induces macrophage phagocytosis of PD-1 ${ }^{+} \mathrm{T}$ cells and IL-10 gene expression}

PBMC-derived type 2 macrophages (M2) express high levels of Fc $\gamma$ RI (CD64) and FcyRII (CD32) (Fig. 3a). Therefore, it is very likely that anti-PD-1 antibody with $\operatorname{IgG} 4_{\mathrm{S} 228 \mathrm{P}}$ Fc may trigger Fc $\gamma$ RI-mediated signaling in macrophages upon binding to PD-1. To test this hypothesis, we investigated whether BGB-A317/IgG4 $4_{\text {S228P }}$ or BGB-A317 could induce macrophage phagocytosis of $\mathrm{PD}-1^{+} \mathrm{T}$ cells (antibody-dependent cell phagocytosis, ADCP). Co-culture of M2 macrophages with HuT78/PD-1 cells in the presence of BGB-A317/IgG4 $4_{\mathrm{S} 228 \mathrm{P}}$ resulted in a significant increase of ADCP. In contrast, treatment with BGB-A317 only had baseline ADCP readouts (Fig. 3b, c). Furthermore, rabbit polyclonal antibody against CD64 could almost completely block BGB-A317/IgG4 ${ }_{\text {S228P }}$-mediated ADCP (Fig. 3d). These results provided the compelling evidence that a PD-1 antibody with FcyRI-binding activity could induce ADCP via crosslinking of PD- $1^{+} \mathrm{T}$ cells and $\mathrm{Fc} \gamma \mathrm{RI}^{+}$macrophages, and Fc $\gamma$ RII seemed not to play any significant role.

Several studies showed that engagement of Fc $\gamma R \mathrm{RI}$ not only induced ADCP, but also activated the gene 


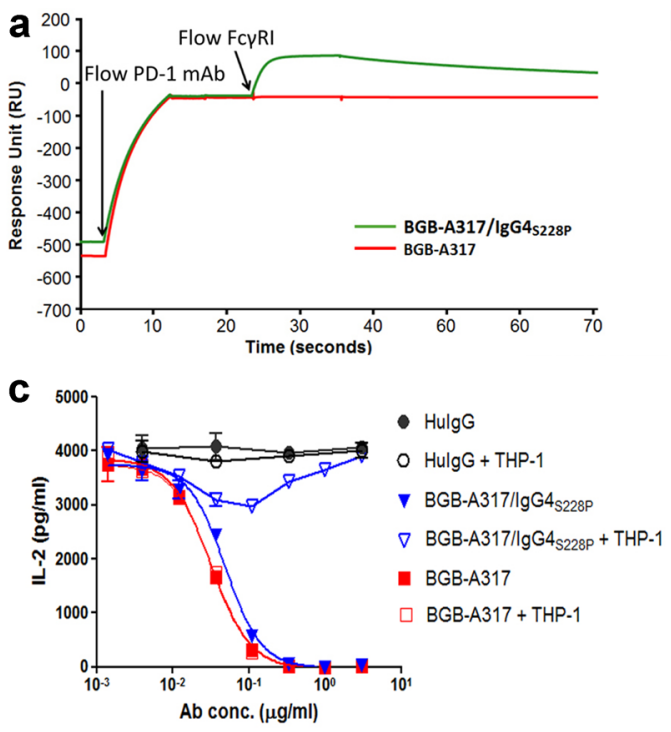

Fig. 2 BGB-A317/IgG4 $4_{S 228 P}$ mediates crosslinking between PD-1 and FcyRI receptors determined by biochemical and cell signaling assays. a Overlaid sensorgrams of BGB-A317 and BGB-A317/ IgG4 $4_{\text {S228P }}$ binding to PD-1 followed by binding with Fc $\gamma$ RI. The PD-1 antibody (either BGB-A317 or BGB-A317//gG4 $4_{S 228 \mathrm{P}}$ ) was injected onto the surface of human PD-1/His-coated CM5 chip, followed by Fc $\gamma$ RI association and dissociation. The arrows indicated the time points when the analytes were injected. b Cartoon interpretation of the SPR assay in (a) showing that BGB-A317/IgG4 ${ }_{\mathrm{S} 228 \mathrm{P}}$ mediates crosslinking between PD-1 and Fc $\gamma$ RI, while BGB-A317 does not. c Comparison of PD-1 antibody functional activities by P3Z assay. In the assays, detection of IL-2 secretion served as a quanti-

transcription of anti-inflammatory cytokine IL-10 in macrophages and promoted M2 macrophage generation [19, 20]. Therefore, we monitored $I L-10$ gene expression in $\mathrm{M} 2$ macrophages after crosslinking of Fc $\gamma$ RI. The assay was performed by seeding $\mathrm{M} 2$ macrophages in PD-1-coated plates in the presence of BGB-A317/IgG4 $4_{\mathrm{S} 228 \mathrm{P}}$ or BGBA317. Quantitative RT-PCR analysis demonstrated that $I L-10$ gene transcription was up-regulated by up to fivefold, when BGB-A317/IgG4 ${ }_{\mathrm{S} 228 \mathrm{P}}$ was added to the cell culture (Fig. 3e). Neither BGB-A317 nor negative control antibodies affect $I L-10$ gene transcription. The results indicated that the anti-PD-1 IgG4 ${ }_{\mathrm{S} 228 \mathrm{P}}$ antibody could engage $\mathrm{Fc} \gamma \mathrm{RI}^{+}$macrophages, induce ADCP and activate transcription of $I L-10$ gene via crosslinking. Furthermore, we determined the cytokine production in the co-culture of M2 macrophages with HuT78/PD-1 cells in the presence of anti-PD-1 antibodies. The results showed that significantly higher amounts of macrophage cytokines (IL-10, IL-8, IL-6 and TNF- $\alpha$ ) [21] were produced after treatment with anti-PD-1/IgG4 ${ }_{\mathrm{S} 228 \mathrm{P}}$ antibodies than that with BGBA317 and control huIgG despite of some cross-individual variations (Suppl. Figure 3). b

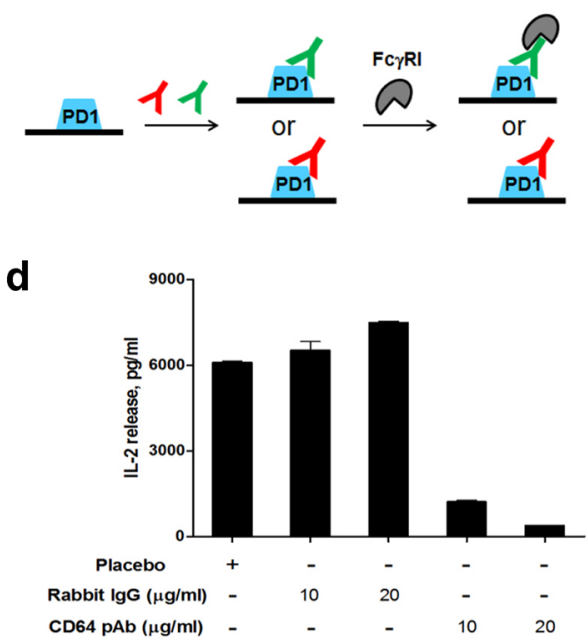

tative indicator of PD-1 signaling. The dose-response was assayed either in the "two-cell line" co-cultures (HuT78/P3Z and HEK293/ PD-L1) presented by solid symbols or in the "three-cell line" system (HuT78/P3Z, HEK293/PD-L1 and Fc $\gamma \mathrm{RI}^{+}$THP-1 cells) presented by open symbols. Ab conc. Antibody concentration. d Rabbit Anti-CD64 $(\mathrm{Fc} \gamma \mathrm{RI} \alpha)$ polyclonal antibody $(\mathrm{pAb})$ restored the inhibitory effect of BGB-A317/IgG4 ${ }_{\mathrm{S} 228 \mathrm{P}}$ on PD-1-signaling in the "three-cell" co-culture system. THP-1 cells were pre-treated with the rabbit Anti-CD64 pAb before co-culturing with HuT78/P3Z and HEK293/PD-L1 cells in the presence of BGB-A317/IgG4 ${ }_{\mathrm{S} 228 \mathrm{P}}$. The placebo contained antibody buffer solution only

\section{BGB-A317 and BGB-A317/lgG4 $4_{\text {S228P }}$ elicited significantly different anti-tumor activities in a xenograft allogenic cancer model}

Because BGB-A317 and BGB-A317/IgG4 $4_{\text {S228P }}$ can only recognize human, but not mouse $\mathrm{PD}-1$, their anti-tumor activity was tested in vivo in a xenograft allogenic cancer model, in which a human tumor cell line A431 and human PBMCs were co-injected subcutaneously into NOD/ SCID mice. As shown in Fig. 4a, b, BGB-A317 exerted significant tumor growth inhibition and the dosages of 1 and $10 \mathrm{mg} / \mathrm{kg}$ did almost equally well (Fig. 4a), whereas $10 \mathrm{mg} / \mathrm{kg}$ of BGB-A317/IgG4 ${ }_{\mathrm{S} 228 \mathrm{P}}$ had no inhibitory effect on tumor growth (Fig. 4b). Analysis of the pharmacokinetics (PK) of the two antibodies ruled out the possibility that the observed differences in their anti-tumor activities were due to the PK or lack of therapeutic antibody in sera, because BGB-A317/IgG4 $4_{\mathrm{S} 228 \mathrm{P}}$ dosed at $10 \mathrm{mg} / \mathrm{kg}$ had much higher AUC and trough sera concentrations than BGB-A317 dosed at $1 \mathrm{mg} / \mathrm{kg}$ (Fig. $4 \mathrm{c}$ and Suppl. Table 2). Therefore, the underlying mechanism at work here appears to be related to differences in the Fc-mediated effector functions. 

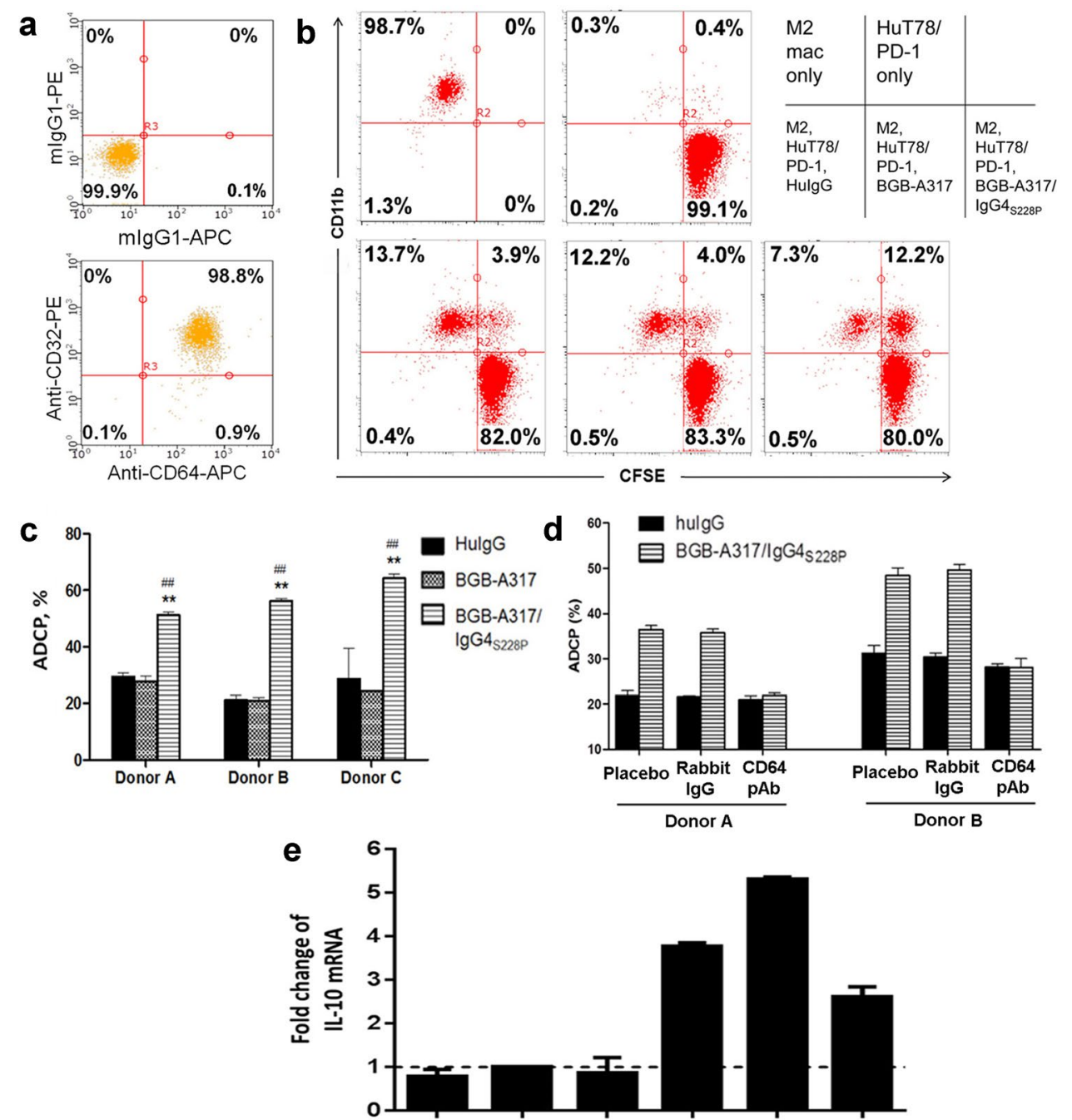

\begin{tabular}{|c|c|c|c|c|c|c|}
\hline Placebo & + & - & - & - & - & - \\
\hline human lgGs $(\mu \mathrm{g} / \mathrm{ml})$ & - & 10 & - & - & - & - \\
\hline BGB-A317 $(\mu \mathrm{g} / \mathrm{ml})$ & - & - & 10 & - & - & - \\
\hline BGB-A317/lgG4s228P $(\mu \mathrm{g} / \mathrm{ml})$ & - & - & - & 10 & 10 & 10 \\
\hline Donor A/M2 & + & + & + & + & - & - \\
\hline Donor D/M2 & + & + & + & - & + & - \\
\hline Donor E/M2 & + & + & + & - & - & + \\
\hline
\end{tabular}

Fig. 3 BGB-A317/IgG4 $4_{\mathrm{S} 228 \mathrm{P}}$ induces primary $\mathrm{M} 2$ macrophages to phagocytose PD- $1^{+} \mathrm{T}$ cells (ADCP) and to express $I L-10$ gene. a CD64 (Fc $\gamma R I)$ and CD32 (Fc $\gamma$ RII) expression on the in vitro differentiated M2 macrophages as determined by FACS. b ADCP assay using M2 macrophages. Primary M2 macrophages were co-cultured with CFSE-labeled PD- ${ }^{+}$HuT78/PD-1 cells overnight in the presence of the indicated antibodies. HuIgG was used as negative control. Representative dot plots of three independent experiments are shown. M2 Mac: M2 macrophage. c Bar graphs summarized the results of three independent experiments. The \% of ADCP was determined as described in the "Materials and methods". The mean + SD represents triplicate data points. ${ }^{\# \#} P<0.01$, comparing BGB-A317/IgG4 ${ }_{\mathrm{S} 228 \mathrm{P}}$ versus huIgG. ${ }^{* *} P<0.01$, comparing $\mathrm{BGB}-\mathrm{A} 317 / \mathrm{IgG} 4_{\mathrm{S} 228 \mathrm{P}}$ versus
BGB-A317. d Rabbit anti-CD64 polyclonal antibody neutralizes Fc $\gamma$ RI-mediated ADCP. Rabbit IgG and placebo were used as negative controls. e Crosslinking of $\mathrm{Fc}_{\mathrm{R}} \mathrm{RI}^{+} \mathrm{M} 2$ macrophages to platecoated PD-1 by BGB-A317/IgG4 $4_{\mathrm{S} 228 \mathrm{P}}$ induces $I L-10$ gene expression. M2 macrophages were added to PD-1-coated 96-well plates in the presence of anti-PD-1 Abs and cultured overnight. The $I L-10$ gene expression was assayed by real-time PCR. $I L-10$ expression in huIgG-treated M2 macrophages was set as a baseline. The mRNA levels of placebo (antibody buffer solution), BGB-A317 or BGB$\mathrm{A} 317 / \mathrm{IgG} 4_{\mathrm{S} 228 \mathrm{P}}$-treated M2 macrophages were normalized against the baseline. The results from three independent experiments are shown as mean + SD of duplicate data points. HuIgG is a mixture of human IgG1, IgG2, IgG3 and IgG4 (Invitrogen) 

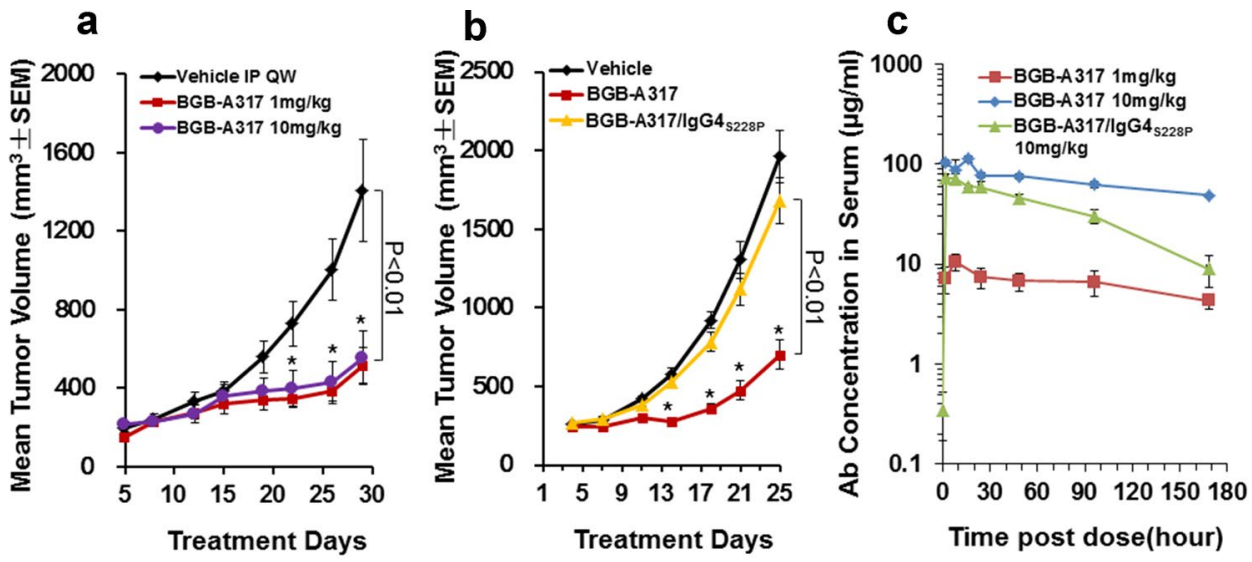

Fig. 4 Anti-tumor activities of BGB-A317 and BGB-A317/IgG4 $4_{\mathrm{S} 228 \mathrm{P}}$ in an allogenic xenograft model. a The anti-tumor activity of BGBA317 at doses of 1 and $10 \mathrm{mg} / \mathrm{kg}$, QW, i.p. was assessed in A431 allogenic xenograft model, in which PBMCs from healthy donors and A431 cancer cells were co-injected subcutaneously into NOD/SCID mice. Each treatment group had ten mice. b The anti-tumor activi-

\section{BGB-A317/lgG4 ${ }_{\text {S228P }}$ enriches murine $\mathrm{FC \gamma RI}^{+}$ macrophages and reduces PD- ${ }^{+}$and $\mathrm{CD8}^{+} \mathrm{T}$ cells in tumor microenvironment (TME)}

Since we observed significantly higher levels of macrophage-mediated ADCP of PD- $1^{+}$T cells with BGB-A317/ $\mathrm{IgG} 4_{\mathrm{S} 228 \mathrm{P}}$ than with BGB-A317 in the in vitro assay, we sought to obtain evidences that similar phenomenon might ties of BGB-A317 $(n=11)$ and BGB-A317/IgG4 $4_{\mathrm{S} 228 \mathrm{P}}(n=13)$ were compared at the same dose of $10 \mathrm{mg} / \mathrm{kg}, \mathrm{QW}$ and in the same model as in (a). c PK curves of BGB-A317 (1 and $10 \mathrm{mg} / \mathrm{kg}, n=3-4)$ and BGB-A317/IgG4 ${ }_{\mathrm{S} 228 \mathrm{P}}(10 \mathrm{mg} / \mathrm{kg}, n=4)$ with a single dose treatment in NOD/SCID mice is shown. The PK parameters are summarized in Suppl. Table 2

occur in TME after anti-PD-1 antibody treatment. Immunofluorescence assay showed that BGB-A317 treatment resulted in the highest density of $\mathrm{CD}^{+}($Fig. $5 \mathrm{a}, \mathrm{b})$ and PD $-1^{+}($Fig. $5 \mathrm{a}, \mathrm{c}) \mathrm{T}$ cells inside tumors. In contrast, BGBA317/IgG4 $4_{\mathrm{S} 228 \mathrm{P}}$ treatment significantly reduced the density of $\mathrm{CD}^{+}$(Fig. 5a, b) and PD- $1^{+} \mathrm{T}$ cells in tumors (Fig. 5a, c). IHC and analysis of fresh tumor tissues by FACS demonstrated similar findings (Suppl. Figure 4).
Fig. 5 The effect of antiPD-1 antibody treatment on tumor-infiltrating $\mathrm{T}$ cells. a Representative images of hCD8 and hPD-1 immunofluorescence staining of tumor tissues from BGB-A317- or BGB-A317/IgG4 ${ }_{\text {S228P }}$-treated mice. $\mathbf{b}, \mathbf{c}$ Quantified result of tumor-infiltrating hCD8 and $\mathrm{hPD}-1$ positive cell numbers in each indicated group $(n=5)$. Ten images were taken for each tumor tissue sample by Vectra. The relative numbers of immunofluorescence-positive cells were quantified using inForm software
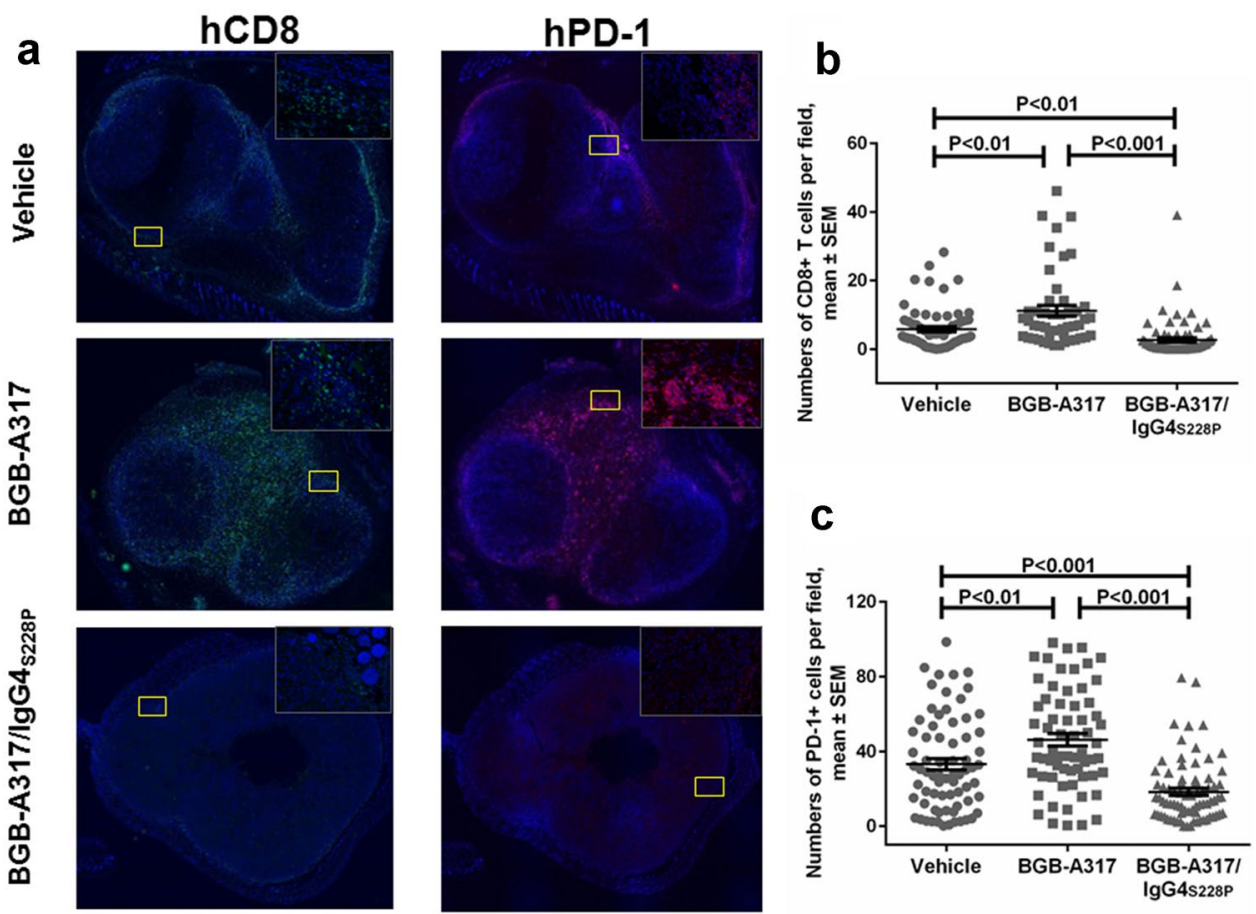

Green: hCD8+ , Read: hPD-1+, Blue: nucleus 
To explore the role of FcyRI (CD64) in the significant reduction of intratumoral PD- $1^{+}$and $\mathrm{CD}^{+}{ }^{+} \mathrm{T}$ cells after BGB-A317/IgG4 $4_{\mathrm{S} 228 \mathrm{P}}$ treatment, tumor tissues were stained for both human CD64 (hCD64) and its mouse counterpart, mCD64, which can also be bound by human IgG4 and mediate the antibody-dependent effector functions via mCD64 ${ }^{+}$cells [22]. The result showed that the density of

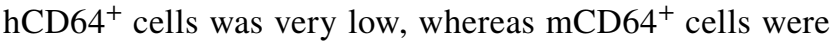
highly enriched in TME (Suppl. Figure 2). A clear inverse correlation of higher density of mCD64 ${ }^{+}$cells and lower density of $\mathrm{CD}^{+} \mathrm{T}$ cells was observed in the tumors treated with BGB-A317/IgG4 $4_{\text {S228P }}$ (Fig. 6a-d). On the contrary,
BGB-A317-treated tumors displayed higher levels of infiltration of $\mathrm{CD} 8^{+} \mathrm{T}$ cells, but lower density of $\mathrm{mCD}^{+} 4^{+}$cells (Fig. 6a-d).

To further clarify the identity of these $\mathrm{mCD} 64^{+}$cells, we performed multiplex immune-fluorescent staining of the tumor tissue sections using antibodies against murine macrophage markers F4/80, CD11b [23, 24], neutrophil marker [25] and mCD64. Our results showed that the majority of tumor-infiltrating mCD64 ${ }^{+}$cells were stained positive with F4/80 and/or CD11b, not with the neutrophil markers, indicating that these $\mathrm{mCD} 64^{+}$cells are mainly murine macrophages not neutrophils (Suppl. Figure 5a). A close

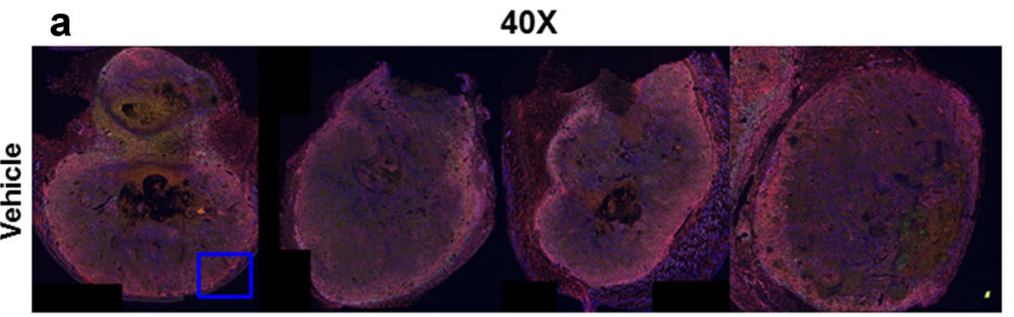

b $\quad 200 x$
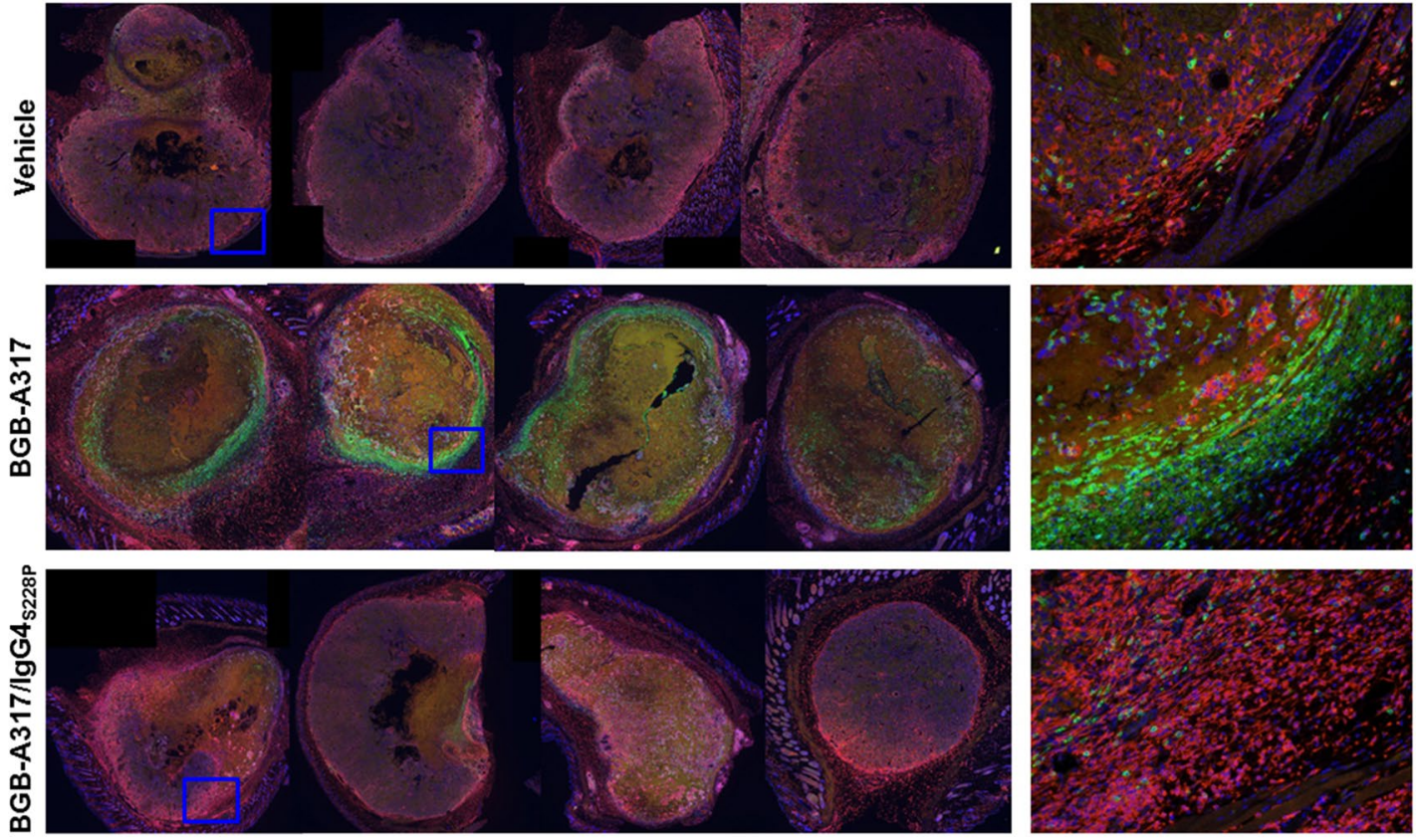

Green: hCD8+, Read: mCD64+, Blue: nucleus

C

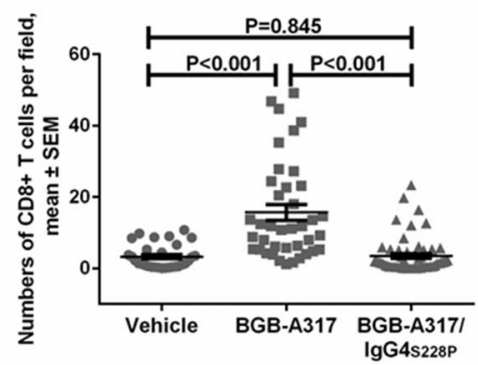

d

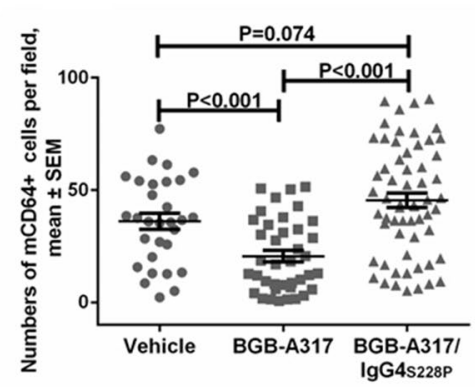

e

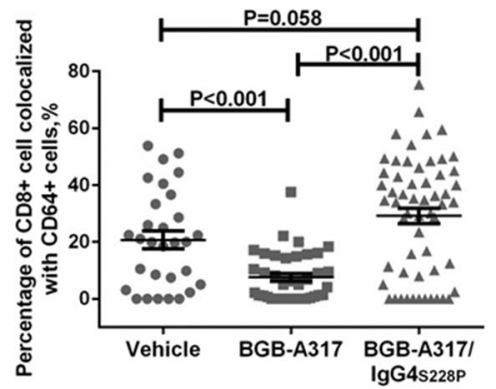

Fig. 6 Crosslinking of $\mathrm{T}$ cells and Fc $\gamma \mathrm{RI}$ positive cells in vivo. a Representative low power $(40 \times)$ images of multiplex immunofluorescence staining of whole mount tumors treated with BGB-A317 or BGB-A317/IgG4 ${ }_{\mathrm{S} 228 \mathrm{P}}$. The xenograft tumor model was generated by subcutaneously implanting the allogenic human epidermoid cancer cells (A341 cell line) and PBMCs in NOD/SCID mice. Representative high power images $(200 \times)$ were shown in $(\mathbf{b})$. The biomarkers are indicated by green (hCD8), red (mCD64) and blue (nucleus), respectively. c-e Quantified results of hCD8, mCD64 staining intensity and co-localization of hCD8 and mCD64 in each indicated group $(n=5)$. Six to ten images in each tumor sample were captured by Vectra, and the staining intensity and co-localization was quantified using inForm software. (Note: CD64 = Fc $\gamma$ RI $\alpha$ ) 
examination of the xenograft tumors further revealed that the hPD- $1^{+} \mathrm{T}$ cells and mCD64 ${ }^{+}$macrophages were frequently localized in contact with each other, implying a high probability of crosslinking of hPD-1 and mCD64 in the presence of BGB-A317/IgG4 ${ }_{\text {S228P }}$ in vivo (Suppl. Figure $5 \mathrm{~b}$ ). In addition, more co-localizations of $\mathrm{hCD}^{+}$and $\mathrm{mCD} 64^{+}$ cells were observed in BGB-A317/IgG4 ${ }_{\mathrm{S} 228 \mathrm{P}}$ treated tumors than the ones treated with BGB-A317 (Fig. 6e). The cytotoxic $\mathrm{T}$ cells (CTLs) in $\mathrm{CD} 8^{+} \mathrm{T}$ cells was identified by the positive staining of perforin, CD107a (Lysosomal-associated membrane protein 1, LAMP1) and granzyme B (Suppl. Figure $6 \mathrm{a}-\mathrm{c}$ ). More CTLs were detected in BGB-A317 treated tumors than those treated with BGB-A317/IgG4 $4_{\text {S228P }}$ (Suppl. Figure 6d-f).

\section{Discussion}

In this report, we showed that the anti-PD-1 mAb with $\mathrm{IgG}_{\mathrm{S} 228 \mathrm{P}}$ retained high affinity binding to Fc $\gamma \mathrm{RI}$ and mediated crosslinking of PD- 1 and Fc $\gamma$ RI, which brought PD- ${ }^{+}$ $\mathrm{T}$ cells and $\mathrm{Fc} \gamma \mathrm{RI}^{+}$macrophages together and induced profound changes in intracellular signaling and biological activities, including the inhibition of PD- $1^{+} \mathrm{T}$-cell functions, induction of ADCP and IL-10 secretion by macrophages. It was well documented that macrophages were present with high frequency and abundance in some cancer types [26]. The high density of macrophages in the TME promote tumor progression, metastasis and resistance to therapies [27-29] and are associated with poor prognosis [30]. In addition, a significant portion of macrophages have been found to be in close contact with $\mathrm{T}$ cells in many human tumors [31, 32]. Thus, the crosslinking of PD- 1 and Fc $\gamma$ RI receptors by an anti-PD-1 $\mathrm{mAb}$ with $\mathrm{IgG}_{\mathrm{S} 228 \mathrm{P}}$ will very likely occur in TME.

PD-1 is highly expressed in T effector cells $\left(\mathrm{T}_{\text {effs }}\right)$ [33]. Immunotherapy with anti-PD-1 antibody is thought to protect PD- $1^{+} \mathrm{T}$ effector cells from PD-1 ligand engagement and its inhibitory effects. Therefore, to avoid possible killing of PD- $1^{+} \mathrm{T}_{\text {effs }}$ through ADCC and CDC, it is desirable to have the effector functions of PD-1 mAb removed. Dahan et al. using Fc $\gamma \mathrm{R}$-null mouse cancer models demonstrated that the anti-tumor efficacy of anti-PD-1 mIgG2a mAbs is significantly better in Fc $\gamma \mathrm{R}$-null than in Fc $\gamma \mathrm{R}$-competent mice. Human IgG4 antibodies usually do not induce significant $\mathrm{ADCC}$ and $\mathrm{CDC}$, since IgG4 binds to Fc $\gamma \mathrm{RIII}$ with very low affinity and lacks binding to $\mathrm{C} 1 \mathrm{q}[10,34,35]$. However, IgG4 antibodies still retain high affinity to Fc $\gamma \mathrm{RI}$ as shown by our SPR assay and others [10]. In line with these findings, therapeutic IgG4 antibodies have been shown to deplete target cells in both humans and a humanized mouse model $[36,37]$. Our in vitro assay showed that BGB-A317/ $\mathrm{IgG}_{\mathrm{S} 228 \mathrm{P}}$ induced significant ADCP than BGB-A317, raising the possibility that $F c \gamma R I$ binding might lead to the killing of PD- $1^{+}$TILs by TAMs and inferior anti-tumor activity. In fact, reduced anti-tumor efficacy was observed in $\mathrm{IgG} 4_{\mathrm{S} 228 \mathrm{P}}$-treated groups as compared with BGB-A317 treatment in a xenograft model. Moreover, fewer numbers of $\mathrm{CD}^{+}$and $\mathrm{PD}-1^{+} \mathrm{T}$ cells within tumors were seen after BGB-A317/IgG4 ${ }_{\text {S228P }}$ treatment, which was also consistent with the presence of high density of murine $\mathrm{CD} 64^{+}$cells within tumors. The results of this study clearly demonstrated that anti-PD-1 antibodies with or without Fc $\gamma$ RI-mediated effector functions exert dramatically different pharmacodynamics effects in anti-cancer activity when there is a high density of $\mathrm{Fc}_{\mathrm{RI}}{ }^{+}$cells (primarily macrophages) present in TME.

There is growing evidence suggesting that Fc $\gamma \mathrm{RI}$ signaling in macrophages may mediate anti-inflammatory effects. Previous studies have shown that ligation of Fc $\gamma R I$ on macrophages could promote the production of the anti-inflammatory cytokine IL-10 and dampen the responses to IFN- $\gamma$ $[19,38]$. In addition, Fc $\gamma R I$ is critical for TGF $\beta 2$-treated macrophage-induced tolerance and plays an important role in IgG4-induced M2 macrophage generation [20, 39]. In a comparative study on the activation of IL-10 production in macrophages, IgG4 has shown similar potency as IgG1 [40].

This study clearly showed that anti-PD-1 antibody with Fc $\gamma$ RI-binding activity had significantly reduced anti-tumor efficacy in the NOD/SCID mouse cancer model with allogenic xenograft of cancer cells (human epidermoid cell line, A431) and human PBMCs. NOD/SCID mice are devoid of $\mathrm{T}$, B cells and IgGs, but have myeloid-derived lineage cells such as macrophages [41]. Therefore, macrophage Fc $\gamma$ RImediated ADCP could efficiently eliminate PD $-1^{+} \mathrm{T}$ cells targeted by a regular PD-1 antibody [42] (also see Fig. 5). In clinic, both nivolumab and pembrolizumab showed clinical efficacy in multiple cancer types [43]. However, the response rate is typically less than $30 \%$. Lack of T-cell infiltration, PD-L1 expression and presence of other checkpoint molecules were attributed to the lack of responses in anti-PD-1 Ab therapy in most patients [43]. We previously compared the efficacy of anti-PD-1 antibodies (BGB-A317, nivolumab and pembrolizumab) using tumor samples from colorectal liver metastasis (CLM) patients [44]. BGB-A317 demonstrated better activation of TILs from CLM tumors where macrophages were more abundant. All these studies suggested that beyond the reasons described above, prevalence of $\mathrm{Fc}_{\mathrm{RI}}{ }^{+}$macrophages infiltration in the TME might also play negative roles in anti-PD-1 antibody (such as nivolumab and pembrolizumab) treatment. Arlauckas et al. recently showed in a mouse model that anti-PD-1 antibody could be transferred from PD- $1^{+} \mathrm{T}$ cells to macrophages via Fc $\gamma R$-dependent manner [45], supporting our findings that tumor-associated macrophages and Fc $\gamma$ RI can negatively impact on anti-PD-1 antibody-mediated anti-tumor efficacy. 
In summary, our study demonstrated that an anti-PD-1 $\mathrm{IgG}_{\mathrm{S} 228 \mathrm{P}}$ antibody could mediate crosslinking between $\mathrm{PD}-1^{+} \mathrm{T}$ cells and $\mathrm{Fc} \gamma \mathrm{RI}^{+}$macrophages, resulting in macrophage-mediated phagocytosis of $\mathrm{PD}-1^{+} \mathrm{T}$ cells, conversion of PD-1 blockade to activating and induction of $I L-10$ gene expression, and, therefore, dampening T-cell-mediated immune responses. Together, the ability to bind FcyRI by an anti-PD- $1 \mathrm{mAb}$ could significantly impair its anti-tumor activity, especially in the TME where macrophages are highly enriched. However, such negative impact on anti-tumor activity should be limited if the effector functions of an anti-PD-1 antibody is removed. Further clinical studies on PD-1 therapy may shed more light on the issue.

Acknowledgements Authors would like to thank Dr. Xiaodong Wang for critics on the studies and for reviewing the manuscript. Authors are also grateful to Drs. Lusong Luo and Min Wei for their valuable suggestions to the studies.

Author contributions KL and LW were involved in the study conceptualization and supervision. TZ, XS, LX, JM, YZ, WG, YZ, XZ, ZW, YW, YS, NL, HB, XY, XC, YC, QL, JS, YL, ZT, and MG were involved in acquisition, analysis, and interpretation of data. TZ, XS, and KL drafted the manuscript and all authors were involved in critical revision of the manuscript.

Funding This work was partially supported by the Biomedical and Life Science Innovation and Cultivation Research Program of the Beijing Municipal Science and Technology Commission under Grant Agreement No. Z151100003915070 (project "Preclinical study on a novel immune oncology anti-tumor drug BGB-A317"), and it was also partially supported by internal company funding for preclinical research.

\section{Compliance with ethical standards}

Conflict of interest All authors have ownership interest in BeiGene. Tong Zhang, Lanlan Xu, Qi Liu., Jing Song and Kang Li are inventors on a patent covering BGB-A317 described in this study.

Research involving human participants and/or animals All procedures performed in studies involving human participants were in accordance with the ethical standards of BeiGene and/or national research committee and with the 1964 Helsinki declaration and its later amendments or comparable ethical standards. All procedures performed in studies involving animals were in accordance with the ethical standards of BeiGene where the studies were conducted

Informed consent Informed consent was obtained from all individual participants included in the study.

Open Access This article is distributed under the terms of the Creative Commons Attribution 4.0 International License (http://creativeco mmons.org/licenses/by/4.0/), which permits unrestricted use, distribution, and reproduction in any medium, provided you give appropriate credit to the original author(s) and the source, provide a link to the Creative Commons license, and indicate if changes were made.

\section{References}

1. Schreiber RD, Old LJ, Smyth MJ (2011) Cancer immunoediting: integrating immunity's roles in cancer suppression and promotion. Science 331:1565-1570. https://doi.org/10.1126/ science. 1203486

2. Swann JB, Smyth MJ (2007) Immune surveillance of tumors. J Clin Investig 117:1137-1146. https://doi.org/10.1172/JCI31405

3. Chen L, Han X (2015) Anti-PD-1/PD-L1 therapy of human cancer: past, present, and future. J Clin Investig 125:3384-3391. https://doi.org/10.1172/JCI80011

4. Keir ME, Butte MJ, Freeman GJ, Sharpe AH (2008) PD-1 and its ligands in tolerance and immunity. Ann Rev Immunol 26:677-704. https://doi.org/10.1146/annurev.immunol.26.02160 7.090331

5. Topalian SL, Hodi FS, Brahmer JR et al (2012) Safety, activity, and immune correlates of anti-PD-1 antibody in cancer. N Engl J Med 366:2443-2454. https://doi.org/10.1056/NEJMoa1200690

6. Garon EB, Rizvi NA, Hui R et al (2015) Pembrolizumab for the treatment of non-small-cell lung cancer. N Engl J Med 372:2018-2028. https://doi.org/10.1056/NEJMoa1501824

7. McDermott DF, Drake CG, Sznol M et al (2015) Survival, durable response, and long-term safety in patients with previously treated advanced renal cell carcinoma receiving nivolumab. J Clin Oncol 33:2013-2020. https://doi.org/10.1200/JCO.2014.58.1041

8. Ferris RL, Blumenschein G Jr, Fayette J et al (2016) Nivolumab for recurrent squamous-cell carcinoma of the head and neck. N Engl J Med 375:1856-1867. https://doi.org/10.1056/NEJMo a1602252

9. Bellmunt J, de Wit R, Vaughn DJ et al (2017) Pembrolizumab as second-line therapy for advanced urothelial carcinoma. N Engl J Med 376:1015-1026. https://doi.org/10.1056/NEJMoa1613683

10. Bruhns P, Iannascoli B, England P, Mancardi DA, Fernandez N, Jorieux S, Daeron M (2009) Specificity and affinity of human Fcgamma receptors and their polymorphic variants for human IgG subclasses. Blood 113:3716-3725. https://doi.org/10.1182/ blood-2008-09-179754

11. Bruhns P (2012) Properties of mouse and human IgG receptors and their contribution to disease models. Blood 119:5640-5649. https://doi.org/10.1182/blood-2012-01-380121

12. Labrijn AF, Buijsse AO, van den Bremer ET et al (2009) Therapeutic IgG4 antibodies engage in Fab-arm exchange with endogenous human IgG4 in vivo. Nat Biotechnol 27:767-771. https:// doi.org/10.1038/nbt.1553

13. Silva JP, Vetterlein O, Jose J, Peters S, Kirby H (2015) The S228P mutation prevents in vivo and in vitro IgG4 Fab-arm exchange as demonstrated using a combination of novel quantitative immunoassays and physiological matrix preparation. J Biol Chem 290:5462-5469. https://doi.org/10.1074/jbc.M114.600973

14. Dahan R, Sega E, Engelhardt J, Selby M, Korman AJ, Ravetch JV (2015) FcgammaRs modulate the anti-tumor activity of antibodies targeting the PD-1/PD-L1 axis. Cancer Cell 28:285-295. https://doi.org/10.1016/j.ccell.2015.08.004

15. Leidi M, Gotti E, Bologna L et al (2009) M2 macrophages phagocytose rituximab-opsonized leukemic targets more efficiently than $\mathrm{m} 1$ cells in vitro. J Immunol 182:4415-4422. https ://doi.org/10.4049/jimmunol.0713732

16. Dai X, Jayapal M, Tay HK et al. (2009) Differential signal transduction, membrane trafficking, and immune effector functions mediated by FcgammaRI versus FcgammaRIIa. Blood 114:318 327. https://doi.org/10.1182/blood-2008-10-184457

17. van der Poel CE, Spaapen RM, van de Winkel JG, Leusen JH (2011) Functional characteristics of the high affinity IgG receptor, FcgammaRI. J Immunol 186:2699-2704. https://doi. org/10.4049/jimmunol.1003526 
18. Grell M, Scheurich P, Meager A, Pfizenmaier K (1993) TR60 and TR80 tumor necrosis factor (TNF)-receptors can independently mediate cytolysis. Lymphokine Cytokine Res 12:143-148

19. Boekhoudt GH, Frazier-Jessen MR, Feldman GM (2007) Immune complexes suppress IFN-gamma signaling by activation of the FcgammaRI pathway. J Leukoc Biol 81:1086-1092. https://doi. org/10.1189/jlb.0906543

20. Swisher JF, Haddad DA, McGrath AG, Boekhoudt GH, Feldman GM (2014) IgG4 can induce an M2-like phenotype in human monocyte-derived macrophages through FcgammaRI. mAbs 6:1377-1384. https://doi.org/10.4161/19420862.2014.975657

21. Arango Duque G, Descoteaux A (2014) Macrophage cytokines: involvement in immunity and infectious diseases. Front Immunol 5:491. https://doi.org/10.3389/fimmu.2014.00491

22. Overdijk MB, Verploegen S, Ortiz Buijsse A, Vink T, Leusen JH, Bleeker WK, Parren PW (2012) Crosstalk between human IgG isotypes and murine effector cells. J Immunol 189:3430-3438. https://doi.org/10.4049/jimmunol.1200356

23. McKnight AJ, Macfarlane AJ, Dri P, Turley L, Willis AC, Gordon S (1996) Molecular cloning of F4/80, a murine macrophagerestricted cell surface glycoprotein with homology to the G-protein-linked transmembrane 7 hormone receptor family. J Biol Chem 271:486-489

24. Murray PJ, Allen JE, Biswas SK et al (2014) Macrophage activation and polarization: nomenclature and experimental guidelines. Immunity 41:14-20. https://doi.org/10.1016/j.immun i.2014.06.008

25. Lopez AF, Strath M, Sanderson CJ (1984) Differentiation antigens on mouse eosinophils and neutrophils identified by monoclonal antibodies. Br J Haematol 57:489-494

26. Zhang QW, Liu L, Gong CY, Shi HS, Zeng YH, Wang XZ, Zhao YW, Wei YQ (2012) Prognostic significance of tumor-associated macrophages in solid tumor: a meta-analysis of the literature. PloS One 7:e50946. https://doi.org/10.1371/journal.pone.0050946

27. Chanmee T, Ontong P, Konno K, Itano N (2014) Tumor-associated macrophages as major players in the tumor microenvironment. Cancers 6:1670-1690. https://doi.org/10.3390/cancers603 1670

28. Noy R, Pollard JW (2014) Tumor-associated macrophages: from mechanisms to therapy. Immunity 41:49-61. https://doi. org/10.1016/j.immuni.2014.06.010

29. Ruffell B, Coussens LM (2015) Macrophages and therapeutic resistance in cancer. Cancer Cell 27:462-472. https://doi. org/10.1016/j.ccell.2015.02.015

30. Bostrom MM, Irjala H, Mirtti T, Taimen P, Kauko T, Algars A, Jalkanen S, Bostrom PJ (2015) Tumor-associated macrophages provide significant prognostic information in urothelial bladder cancer. PloS One 10:e0133552. https://doi.org/10.1371/journ al.pone. 0133552

31. Zhao Q, Kuang DM, Wu Y, Xiao X, Li XF, Li TJ, Zheng L (2012) Activated CD69+ T cells foster immune privilege by regulating IDO expression in tumor-associated macrophages. J Immunol 188:1117-1124. https://doi.org/10.4049/jimmunol.1100164

32. Tsujikawa T, Kumar S, Borkar RN et al. (2017) Quantitative multiplex immunohistochemistry reveals myeloid-inflamed tumor-immune complexity associated with poor prognosis. Cell Rep 19:203-217. https://doi.org/10.1016/j.celrep.2017.03.037

33. Nishimura H, Honjo T (2001) PD-1: an inhibitory immunoreceptor involved in peripheral tolerance. Trends Immunol 22:265-268

34. Davies AM, Sutton BJ (2015) Human IgG4: a structural perspective. Immunol Rev 268:139-159. https://doi.org/10.1111/ imr.12349

35. Wang C, Thudium KB, Han M et al. (2014) In vitro characterization of the anti-PD-1 antibody nivolumab, BMS-936558, and in vivo toxicology in non-human primates. Cancer Immunol Res 2:846-856. https://doi.org/10.1158/2326-6066.CIR-14-0040

36. Lux A, Seeling M, Baerenwaldt A et al. (2014) A humanized mouse identifies the bone marrow as a niche with low therapeutic IgG activity. Cell Rep 7:236-248. https://doi.org/10.1016/j.celre p.2014.02.041

37. Isaacs JD, Wing MG, Greenwood JD, Hazleman BL, Hale G, Waldmann H (1996) A therapeutic human IgG4 monoclonal antibody that depletes target cells in humans. Clin Exp Immunol 106:427-433

38. Sutterwala FS, Noel GJ, Salgame P, Mosser DM (1998) Reversal of proinflammatory responses by ligating the macrophage Fcgamma receptor type I. J Exp Med 188:217-222

39. Gu Z, Chhabra AY, Alard P, Warner DR, Kosiewicz MM (2013) FcgammaRI is required for TGFbeta2-treated macrophageinduced tolerance. Immunobiology 218:1200-1206. https://doi. org/10.1016/j.imbio.2013.04.003

40. Kinder M, Greenplate AR, Strohl WR, Jordan RE, Brezski RJ (2015) An Fc engineering approach that modulates antibodydependent cytokine release without altering cell-killing functions. mAbs 7:494-504. https://doi.org/10.1080/19420862.2015.10226 92

41. Shultz LD, Schweitzer PA, Christianson SW et al. (1995) Multiple defects in innate and adaptive immunologic function in NOD/ LtSz-scid mice. J Immunol. 154:180-191

42. Gillis C, Gouel-Cheron A, Jonsson F, Bruhns P (2014) Contribution of human FcgammaRs to disease with evidence from human polymorphisms and transgenic animal studies. Front Immunol 5:254. https://doi.org/10.3389/fimmu.2014.00254

43. Zou W, Wolchok JD, Chen L (2016) PD-L1 (B7-H1) and PD-1 pathway blockade for cancer therapy: mechanisms, response biomarkers, and combinations. Sci Transl Med 8:328rv4. https://doi. org/10.1126/scitranslmed.aad7118

44. Luo L, Wu X, Zhang T et al (2017) Abstract 5626: Investigation of $\mathrm{T}$ cell activation by anti-human PD-1 antibodies nivolumab, pembrolizumab and BGB-A317 using tumor-infiltrating lymphocytes (TILs) from colorectal cancer and colorectal liver metastasis patients. Cancer Res 77:5626. https://doi.org/10.1158/1538-7445. am2017-5626

45. Arlauckas SP, Garris CS, Kohler RH et al (2017) In vivo imaging reveals a tumor-associated macrophage-mediated resistance pathway in anti-PD-1 therapy. Sci Transl Med. https://doi.org/10.1126/ scitranslmed.aal3604 